\title{
Late Medieval and Modern Ceramics from the Castle in Przezmark in the Light of the Results of Gas Chromatography Coupled with Mass Spectrometry - an Attempt at Interpretation
}

\author{
Późnośredniowieczna i nowożytna ceramika zamkowa \\ w Przezmarku w świetle wyników chromatografii gazowej sprężonej ze \\ spektrometrią mas - próba interpretacji
}

\begin{abstract}
Archaeological excavations of the Institute of Archaeology UKsw lasted from July to August 2017. Principals have reviewed the area. In the first season, four excavations were opened - three $(\mathrm{A}-\mathrm{C})$ ones in the high castle and one (D) in the middle castle area. Trench $\mathrm{A}$ was founded on the outside of the south-eastern corner of the castle. The work was to verify the presence of the external wall - it was built from the side of the lake, present on the plans of the castle. During the excavation tests, the remains of the toilet tank were unveiled.
\end{abstract}

Fragments of usable ceramics were extracted from these places. Samples were taken from vessels and transferred to the laboratory. During the chemical analysis, fatty acids were isolated. Based on the proportion of acids obtained, an attempt was made to interpret food prepared in dishes. The following tests were chosen for the tests: lid (PI), six den ( $\mathrm{P} 2, \mathrm{P} 3, \mathrm{P} 4, \mathrm{P} 5, \mathrm{P} 6, \mathrm{P} 7)$, two bellies (P9, PIO) and two outlets (P8 and PII). After an overall analysis, it was found that FAME of plant and animal origin was detected in all samples.

Keywords: ceramics, gas chromatography compressed with mass spectrometry, chemical analysis, Przezmark

Chemical analyzes applied to archaeological monuments may constitute an important element complementing the results of archaeological research. One method that can be used to obtain additional information on vessels from excavation work is gas chromatography coupled with mass spectrometry. These studies make it possible to determine what food products were prepared in the dishes. Such an analysis was carried out in the case of eleven unglazed vessels obtained during the archaeological work carried out in the castle in Przezmark. Ceramic vessels from the late Middle Ages and early modern times were selected and prepared for 
the research. The results of the research obtained on the basis of qualitative and quantitative analysis of fatty acids contained in the walls of ceramic vessels are presented below. The results described are a contribution to the further development of the topic related to the research conducted on the reconstruction of the contents of single ceramic vessels.

\section{Historical background}

During the excavation works at the Teutonic Knights castle in Przezmark, commune Stary Dzierzgon (AZP 22-51, site 6) in 2017, the latrine of the upper castle was explored ${ }^{1}$, from which numerous fragments of late-medieval and early-modern kitchen ceramics, building ceramics and everyday objects were excavated (Fig. I). The abundance of ceramic material preserved in relatively large fragments led to the assumption that the samples obtained from them could be tested for the presence of fatty acids, which would provide data for dietary research in the late Middle Ages and early modern times.

The castle in Przezmark was erected in the years 1316-1331 on a headland cutting into Lake Motława Wielka ${ }^{2}$. It belonged to the Dzierzgoń commandry and was the seat of lower order officials until I4I4, when a convent was moved
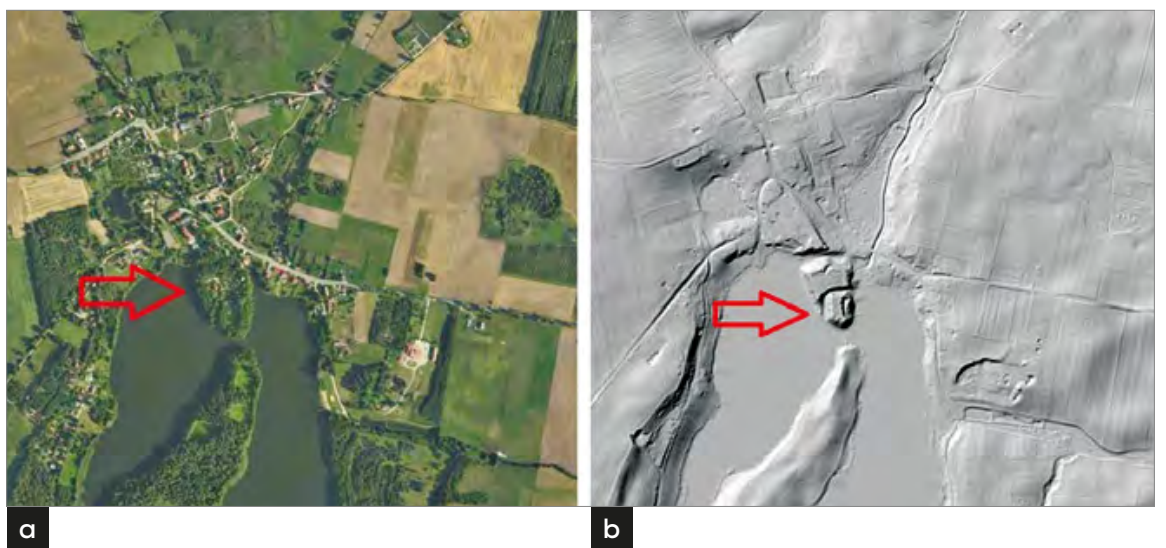

Fig. 1. Location of the Teutonic castle in Przezmark on a scale of $\mathrm{I}$ : Io ooo,

a) orthophoto map, b) Numerical Terrain Model from the IsoK project (source: Geoportal.gov.pl, https://mapy.geoportal.gov.pl/imap/Imgp_2.html?gpmap=gpo).

1 Archaeological research was conducted by the Institute of Archeology of the Cardinal Stefan Wyszyński University in Warsaw, and led by Dr. Magdalena Zurek.

2 The history of the castle in Przezmark, after: Haftka 2010. 


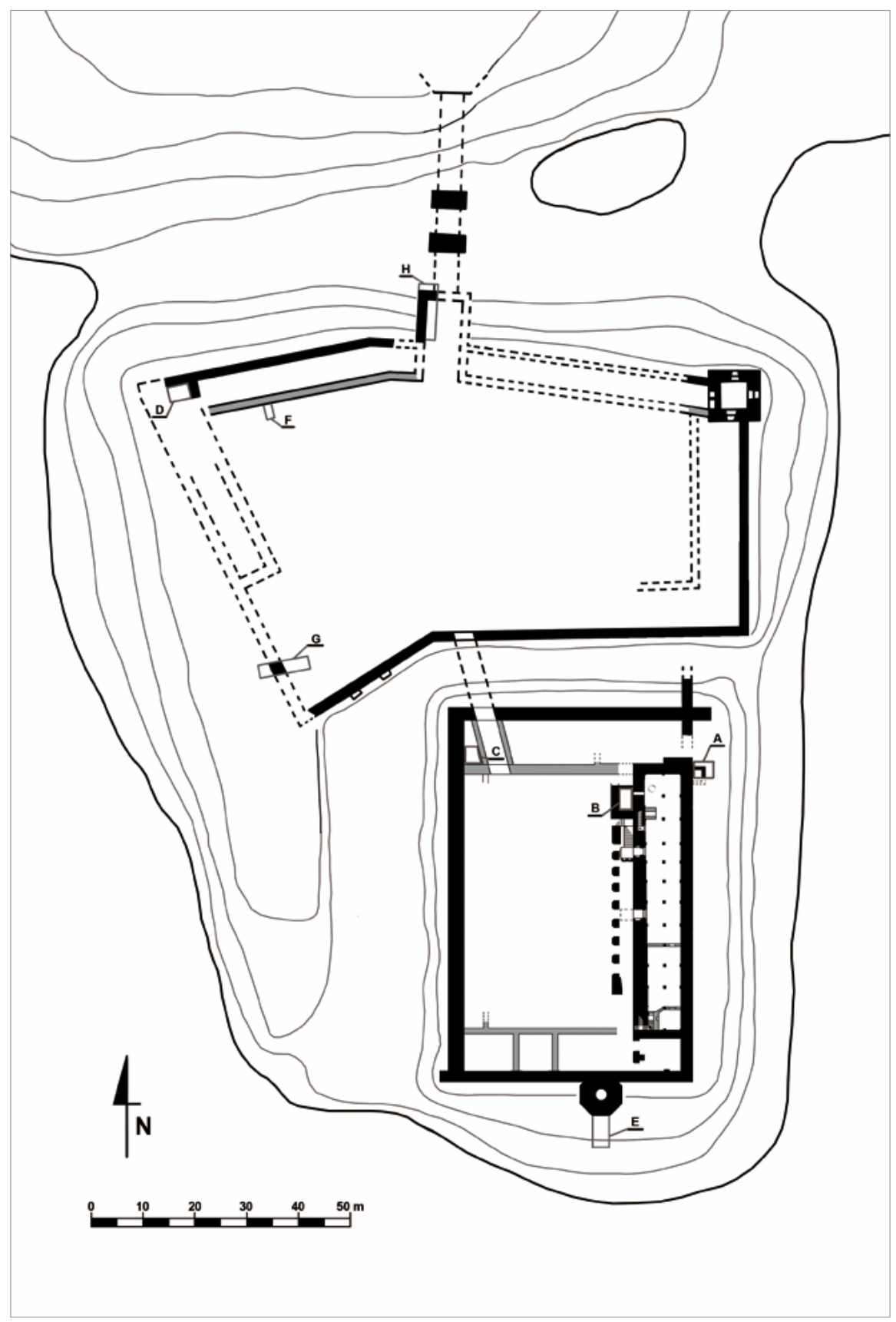

Fig. 2. Plan of the castle on the basis of available historical knowledge and information obtained from archaeological research (edited by M. Żurek). 


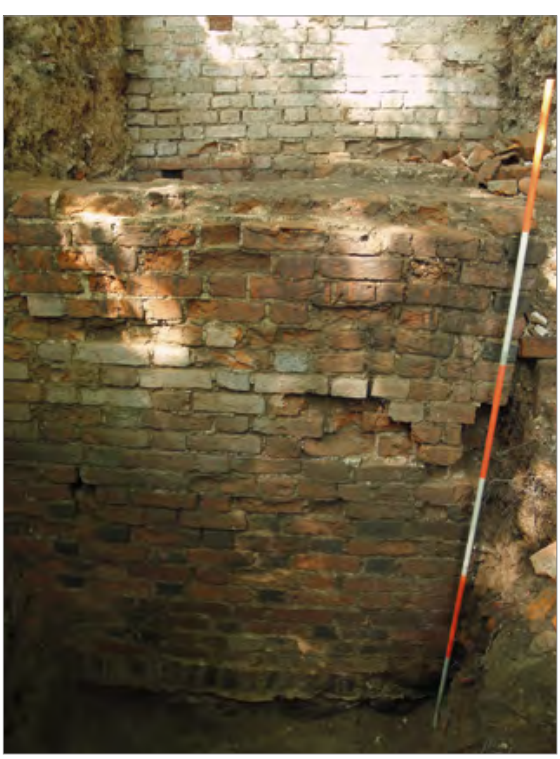

Fig. 3. The latrine reservoir located on the upper castle (photo by M. Żurek).

here from the commander's castle in Dzierzgoń, destroyed during wars with Poland. After the secularization of Ducal Prussia in I525, it passed into private hands, and finally became the seat of the Upper Prussian starosty. In the period in question, the complex consisted of a middle and high castle, with brick buildings around the inner courtyards. As early as in the $18^{\text {th }}$ century, the castle gradually fell into disrepair, until it was finally abandoned and its partial demolition began. In the years 1931-1934, the high castle was subjected to conservation (Wunschi935: 32-44). Securing the walls of the upper castle was also carried out at the end of the 1950s in connection with the organization of a holiday center on its premises. At that time, sanitary installations were also built into the existing $14^{\text {th }}$-century tower and pavilions in the courtyard of the middle ward. In 2000 , the castle passed into private hands.

Documentation and excavation works carried out by the Institute of Archeology of the Cardinal Stefan Wyszyński University in Warsaw focused mainly on the area of the upper castle (excavations $\mathrm{A}-\mathrm{C}$ and $\mathrm{E}$ ). In addition, three excavations were established in the area of the middle ward (excavations D, F-H). The aim of the work was to establish the chronology of construction and verify the plan of the castle.

The explored latrine was located in the upper castle, at its north-east corner, on the eastern side of the perimeter wall (Fig. 2). The toilet room was probably about $2.7 \times 3.4 \mathrm{~m}^{3}$. Its walls were wooden. The entry level to it was $3.0 \mathrm{~m}$ above the top of the reservoir walls. An entrance in the eastern perimeter wall of the building led to the room, closed with a semicircular arch, $188 \mathrm{~cm}$ high and $65 \mathrm{~cm}$ wide. The entrance was closed and blocked with a horizontal beam - two holes for a beam $158 \mathrm{~cm}$ (north) and $138 \mathrm{~cm}$ (south) deep were preserved in the wall.

The reservoir, preserved in full height, was added to the castle wall, but the presence of an entrance opening to the toilet room, made during the construction of the wall, proves that its construction was planned there. The $250 \mathrm{~cm}$ high reservoir measured $2.7 \times 3.4 \mathrm{~m}$ (Fig. 3). It was built of bricks in an anvil thread, on a stone foundation and a foundation roll. Its walls were $90 \mathrm{~cm}$ wide, and the high bottom was paved with several layers of brick, thanks to which the reservoir itself 
was just over $100 \mathrm{~cm}$ deep. From the south, the reservoir was open, which made it possible to empty it ${ }^{3}$.

Four layers are distinguished in the latrine filling. Above the tank floor there was a compact layer of faeces with a thickness of $\mathrm{I5}-\mathrm{I} 9 \mathrm{~cm}$ (W.038), above it a layer with a thickness of approx. $25 \mathrm{~cm}$, containing construction rubble with lots of ceramic tiles, medieval pottery, sparse lumps of slag and iron spike (In .033). In part of the reservoir there is a thin layer of gray loose sand (W.03I) in which a weaving weight has been placed. Above it, on the entire surface of the tank, there is a thin layer of crushed mortar (w.030). The last layer, up to the crown of the reservoir walls is gray, loose with a thickness of approx. $50 \mathrm{~cm}$ (w.o19), containing numerous fragments of pottery and building ceramics, as well as a bone plate constituting a fragment of a clock, a chain link, a copper ring, a pin in the form of a rooster and a fragment of brown fittings. The w.or 6 layer, lying directly on the crown of the reservoir walls and its filling, consists of construction debris, lumps of mortar and sand, also fragments of earthenware vessels, plate tiles with green glaze and four fragments of homogeneous Gouda pipes, one of which contained the inscription IAC.DEVOSS, allowing the product to be spent on the second quarter of the $18^{\text {th }}$ century ${ }^{4}$.

A large collection of utility ceramics was also excavated from the latrine filling, including many fragments of cookware and tablewares.

\section{Selected ceramic vessels - description of samples}

From among the excavated fragments of pottery, twelve were selected from late-medieval and early-modern vessels, including two glazed fragments. They were divided into smaller groups according to the form. In this way, the following fragments were distinguished: one lid ( $\mathrm{PI}$ ), five deniers ( $\mathrm{P} 2, \mathrm{P} 3, \mathrm{P} 4, \mathrm{P} 5, \mathrm{P} 6)$, two bellies (P9, $\mathrm{PIO})$, two infusions (P8 and PII) and one complete form - the P7 cup (Fig. 4, 5):

PI - fragment of gray ceramics - lids $13.5 \mathrm{~cm}$ in diameter;

P2 - ragment of gray ceramics - a thick-walled belly with a bottom of the pot with a diameter of $11.5 \mathrm{~cm}$, there are faint traces of cutting off the vessel from the circle at the bottom;

$\mathrm{P}_{3}$ - fragment of blackened ceramics - a pot with a bottom, $16 \mathrm{~cm}$ in diameter;

3 This explains the low depth of the reservoir and the presence of relatively few medieval relics in the excavated material. Most of the items were dated to the early modern era.

4 The manufacturer of pipes, Iacob de Vos, is mentioned in 1729 and 1749 (Van der Meulen 2003: 41, 69).

5 Preliminary report on the excavation work in 2017 in Żurek 2018. 
$\mathrm{P} 4$ - fragment of the pot in a brick-orange color - preserved belly with a fragment of the bottom $9.5 \mathrm{~cm}$ in diameter, visible admixture of medium-sized grains, streaks of glaze are visible inside the vessel;

P5 - fragment of a pot of blackened ceramics - the bottom part is poorly preserved, and the bottom itself has a diameter of $13.5 \mathrm{~cm}$, at the bottom, there are barely visible traces of cutting off from the circle;

P6 - a fragment of a brown pot - preserved belly and bottom with a diameter of II cm;

P7 - fragment of gray ceramics - bowls with a spout diameter of $10.2 \mathrm{~cm}$, a bottom diameter of $6.4 \mathrm{~cm}$ and a height of $3.2 \mathrm{~cm}$. The cup is shallow, with straight, relatively steep sides with a comb decoration and a poorly separated, flat foot. In the preserved fragment of the bottom, there are three holes $0.3 \mathrm{~cm}$ in diameter, which were pierced from the inside of the vessel. There are traces of cutting the cup from the circle on the foot;

P8 - fragment of brick ceramics on the outside with brown glaze - preserved pot with a spout with a diameter of $15 \mathrm{~cm}$;

P9 - a fragment of brick ceramics with a thick lens of brown enamel visible in one place inside. There are traces of soot on the outside of the vessel walls; PIO - fragment of gray ceramics - pot belly;

PII - fragment of gray ceramics - a jug with a spout, $\mathrm{IO} \mathrm{cm}$ in diameter.
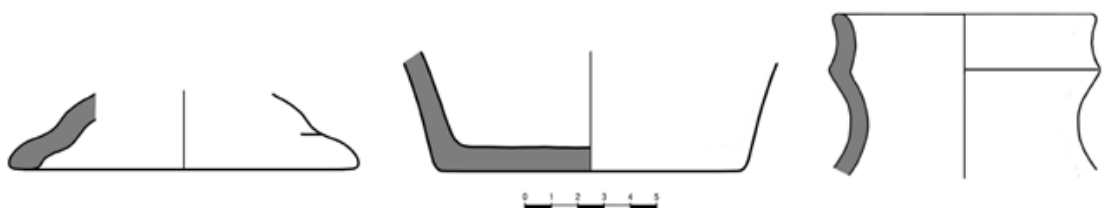

Fig. 4. Selected pottery for chemical analyses - from the left, sample no I, 2 and II (edited by M. Żurek).

Fragments of ceramic vessels, after being removed from inside the latrine, were washed in water to remove the dried-on remains of the object's fill. The next ones were placed in paper envelopes (as recommended by a laboratory worker). The described fragments were sent to the laboratory for chemical analyzes of the quantitative and qualitative composition of fatty acids in the walls of ceramic vessels. Various forms of vessels, including a lid, were submitted for chemical research to assess the possibility of fatty acids penetrating from food into the porous walls of ceramic vessels. In the case of the above-mentioned lid, the question was raised whether there is a possibility that it could come into contact with heat-treated food - if fatty acids are extracted, it will mean that such action was practiced. 


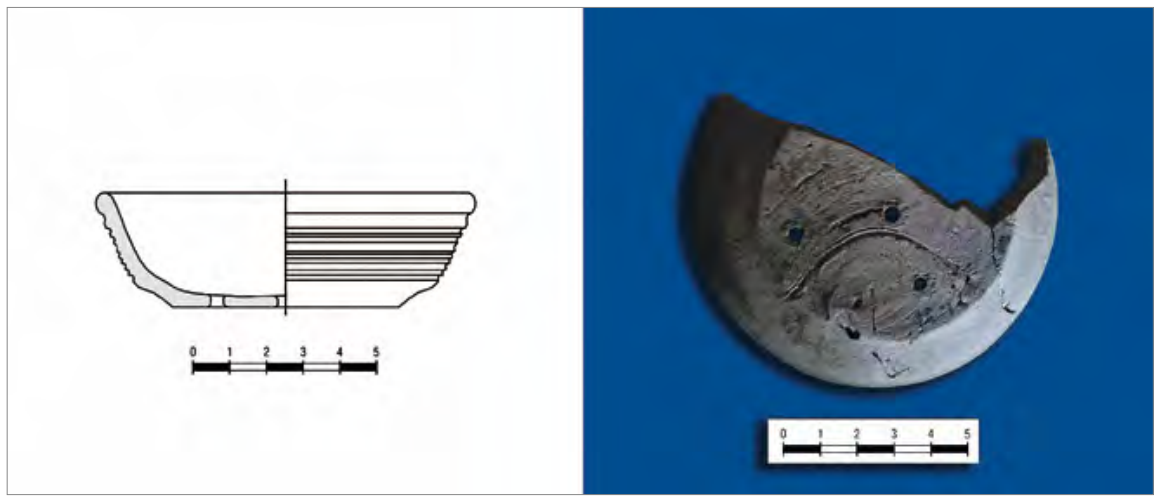

Fig. 5. A drawing and a photograph of a bowl found in a latrine - sample no 7 (drawing and photo by M. Żurek).

\section{Chemical analysis of the content of ceramic vessels}

The aim of the chemical analysis was to try to identify the food prepared in the above-mentioned vessels. In addition, it prolonged the extraction of fatty acids, which, as a result of preparing and heating dishes, penetrated the walls of the dishes. These compounds were extracted using gas chromatography coupled to mass spectrometry. Having obtained individual fatty acids of animal and vegetable origin, it is possible to try to interpret what was once in the vessels. For this purpose, the ratios of selected fatty acids are compiled in accordance with the formulas proposed by the researchers ${ }^{6}$.

It should be emphasized that fatty acids penetrate the pores of the ceramics of the vessel walls as a result of high temperature. Therefore, it was assumed that the dishes should contain food that was previously cooked in them or otherwise heat-treated (Kałużna-Czaplińska, Młodecka 2008: I05-IIO). Based on the analysis of previous studies conducted by various researchers, it was concluded that the influence of the environment in which the vessel fragments were located, including the bacteria found in the soil, does not have a significant effect on the behavior of fatty acids (see Rosiak et al.; Żurowicz et al. 20I4: 50-53; Kałużna-Czaplińska et al. 2016: 173-209; Orliński, Zdeb 2017: 135-144; Pavelka, Orna 2011: 95-96). Due to this fact, it was not decided to collect samples of the latrine fill for laboratory test.

6 The methods proposed by Dudda et al. 1999; Gregg, Slater 2010; Isaksson 2000; Hjulström et al. 2008; Regert 20II; Eerkens 2005, were adopted and are described below. 


\section{Method of obtaining fatty acids}

Chemical analysis was carried out at the Laboratory of the Institute of Ecology and Biology of the Cardinal Stefan Wyszyński University in Warsaw. In the laboratory, a layer of clay was scraped off the surface of the vessel walls, and then from the inside of the wall at a depth of approx. $2 \mathrm{~mm}$, samples were taken for further tests. The material obtained in this way allows to avoid erroneous chemical analysis of sediments that could adhere to the walls of the vessels from the outside or come from the hands of researchers or laboratory technicians who, after washing the fragments of dishes, could accidentally contaminate them again.

Determination of fatty acids was performed by gas chromatography with a single quadrupole mass detector (GC-MS). It enables the simultaneous determination of almost fifty fatty acids (FAME) and is characterized by very high sensitivity and precision. The prerequisite for this method is the extraction of fatty acids from the sample and their methylation, followed by esterification in order to obtain fatty acid methyl esters (EMKT). Only in this form is it possible to carry out a qualitative and quantitative analysis of the obtained fatty acids. In order to obtain FAME, the so-called the direct method, which consisted in subjecting the lipids contained in the ceramic samples directly to alkaline hydrolysis, omitting extraction ${ }^{7}$.

\section{Result analysis}

In order to analyze the content of ceramic vessels obtained from the archaeological research conducted in the castle in Przezmark, formulas of proportions of selected fatty acids and the analysis of the remaining lipids from the extracted lipids were used (Tab. I). These methods, adopted by Polish researchers, allow for an attempt to isolate meat, fish and plant foods. However, due to the fact that in some cases quite imprecise results are obtained, several different formulas are used for the analyzes, given below, in order to obtain the most accurate data possible (Rosiak et al.; Orliński, Żurowicz et al. 2014: 50-53; Kałużna-Czaplińska et al. 2016: 173-209; Zdeb 2017: 135-144).

After general analysis of the extracted fatty acids, it can be concluded that FAME of plant and animal origin was detected in all samples.

Among the obtained lipids, a group of waxes of plant origin was distinguished, which occur mainly on fruits and leaves, e.g. lemon balm and wax maker. A C30: 0 fatty acid which can be extracted from lemon balm has been detected. In addition, animal waxes - insect waxes were detected. The last group of waxes is secreted by

7 The description of the method was prepared by Maciej Sierakowski, MA from the Laboratory of the Institute of Ecology and Biology, UKsw. 
Tab. 1. Fatty acids extracted from I2 samples taken from pottery fragments.

\begin{tabular}{|c|c|c|c|c|c|c|c|c|c|c|c|c|c|c|}
\hline \multirow[b]{2}{*}{ zo } & \multirow{2}{*}{ 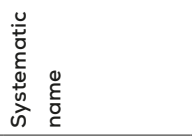 } & \multirow{2}{*}{ 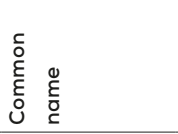 } & \multirow{2}{*}{ 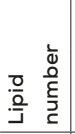 } & \multicolumn{11}{|c|}{ Pottery fragments (ug/ml) } \\
\hline & & & & P1 & $\mathrm{P} 2$ & P3 & P4 & P5 & P6 & P7 & P8 & P8 & $\mathrm{P} 10$ & P11 \\
\hline 1 & Hexanoicacid & Caproicacid & c6:0 & 0,191 & - & - & - & 0,326 & - & 0,132 & - & - & 0,095 & - \\
\hline 2 & Octanoicacid & Caprylicacid & c8:0 & - & - & 0,164 & - & - & - & - & - & - & - & - \\
\hline 3 & Decanoicacid & Capricacid & $\mathrm{c} 10: 0$ & 0,542 & - & 0,342 & - & - & - & - & - & - & - & - \\
\hline 4 & Undecanoicacid & Undecylicacid & $\mathrm{C} 11: 0$ & 0,111 & - & 0,273 & - & - & - & - & - & - & - & - \\
\hline 5 & Dodecanoicacid & Lauricacid & $\mathrm{C} 12: 0$ & 1,173 & 0,051 & 0,392 & 0,77 & 0,436 & 0,168 & 0,191 & 0,08 & 0,563 & 0,607 & 0,119 \\
\hline 6 & Tridecanoicacid & Tridecylicacid & $\mathrm{C} 13: 0$ & 0,111 & 0,041 & 0,378 & 0,24 & 0,053 & 0,056 & 0,051 & - & 0,074 & 0,057 & - \\
\hline 7 & Tetradecanoicacid & Myristicacid & c14:0 & 3,086 & 0,504 & 4,243 & 3,27 & 1,965 & 1,07 & 0,437 & 0,497 & 2,892 & 0,973 & 0,906 \\
\hline 8 & Pentadecanoicacid & Pentadecanoicacid & $\mathrm{C} 15: 0$ & 0,917 & 0,273 & 1,78 & 1,61 & 0,564 & 0,442 & 0,226 & 0,384 & 0,714 & 0,497 & 0,314 \\
\hline 9 & $\begin{array}{l}\text { (9z)-Hexadec-9- } \\
\text {-enoic acid }\end{array}$ & Palmitoleicacid & $\begin{array}{l}\mathrm{C} 16: 1 \\
\mathrm{n}-7\end{array}$ & - & - & 0,324 & - & - & - & - & - & 0,622 & - & - \\
\hline 10 & Hexadecanoicacid & Palmiticacid & c16:0 & 15,744 & 5,312 & 44,345 & 22,04 & 16,399 & 7,539 & 2,703 & 3,446 & 25,704 & 7,821 & 7,952 \\
\hline 11 & Heptadecanoicacid & Margaricacid & $\mathrm{C} 17: 0$ & 0,861 & 0,448 & 6,933 & 1,325 & 0,92 & 0,416 & 0,165 & - & 1,575 & 0,446 & 0,424 \\
\hline 12 & $\begin{array}{l}\text { (9z, 12z)-octadeca- } \\
-9,12 \text {-dienoic acid }\end{array}$ & Linoleicacid & $\begin{array}{l}\mathrm{C} 18: 2, \\
\mathrm{n}-6\end{array}$ & 0,253 & 0,18 & 0,257 & - & 0,162 & 0,156 & 0,27 & - & 0,326 & 0,117 & 0,109 \\
\hline 13 & $\begin{array}{l}\text { (9z)-Octadec-9- } \\
\text {-enoic acid }\end{array}$ & Oleic acid & $\begin{array}{l}\text { c18:1, } \\
n-9\end{array}$ & 2,475 & - & 8,599 & 2,165 & 4,308 & 1,941 & 0,415 & - & 11,835 & 0,708 & 0,617 \\
\hline 14 & Octadecanoicacid & Stearicacid & C18:0 & 13,752 & 6,006 & 63,287 & 15,46 & 12,491 & 6 & 1,322 & 2,594 & 21,909 & 7,31 & 6,986 \\
\hline 15 & Nonadecanoic & Nonadecylicacid & $\mathrm{c} 19: 0$ & + & + & + & + & + & + & + & + & + & + & + \\
\hline 16 & Eicosanoicacid & arachidicacid & c20:0 & 0,237 & 0,091 & 1,052 & 0,505 & 0,302 & 0,109 & 0,049 & 0,073 & 0,452 & 0,126 & 0,137 \\
\hline 17 & Heneicosanoicacid & Heneicosylicacid & $\mathrm{c} 21: 0$ & 0,177 & 0,105 & 0,445 & 0,61 & 0,162 & 0,12 & 0,094 & 0,11 & 0,179 & - & 0,123 \\
\hline 18 & Docosanoicacid & Behenicacid & c22:0 & 0,199 & 0,113 & 0,417 & 0,58 & 0,316 & 0,098 & 0,053 & 0,091 & 0,358 & 0,107 & 0,104 \\
\hline
\end{tabular}


the abdominal glands of insects. Among insect waxes, beeswax, i.e. C28: 0 , and the other two fatty acids $\mathrm{C} 26: 0$ and $\mathrm{C} 27: 0$, also produced by insects, are more precisely defined. For five of all samples ( $\left.\mathrm{P}_{3}, \mathrm{P}_{4}, \mathrm{P} 5, \mathrm{P} 8, \mathrm{P} 6\right)$ all four waxes were detected, but only two wax species were detected in the other two vessels. It is possible that the insides of these vessels were waxed. This process was supposed to seal the inside of the vessels to make their walls impermeable (Salque et al. 2013; Čiperová et al. 2015: 203-207).

Next, an attempt was made to interpret meat foods based on the analysis of fatty acids of animal origin. In order to confirm the presence of these acids in the tested samples, in the first one, the division proposed by M.W. Gregg and G.F. Slater, the base of which is the ratio of palmitic (Cı6: o) and stearic (Cı8: O) acids. In the case of animal fatty acids, the obtained result is in the range of I to $2 \mu \mathrm{g} / \mathrm{mL}$. On the other hand, vegetable fatty acids are characterized by results above $3 \mu \mathrm{g} / \mathrm{mL}$ (Gregg, Slater 2010: 833-854). On this basis, it was found that eleven samples contain fatty acids of animal origin. However, the results from sample no. 7 (obtained from a fragment of the bottom of the vessel) were at the borderline. The result was found to be $2.045 \mu \mathrm{g} / \mathrm{mL}$. It should only be assumed that the content also in this case was of animal origin due to the slight deviation from the established threshold.

Due to the animal origin of some of the acids obtained from the walls of the vessels, an analysis of the type of meat was carried out. To determine whether the meat belonged to ruminants or monogastric animals, the proportions of the above-mentioned stearic (Ci8: O) and palmitic (Ci6:0) acids were used. The method proposed by $M$. Regert was used for this, where in the case of monogastric animals, the sample should show the advantage of palmitic acid (Cı6:0) over stearic acid (Cı8: O), and also oleic acid (Cr8: I n-9) should be detected. On the other hand, ruminant meat can be interpreted on the basis of the advantage of Ci8: $O$ over Ci6: $O$ along with the presence of pentadecanoic (CI5: O) and margaric (C17: O) acids (Regert 200I: 177-220). Thus, the remains of the contents of eleven vessels were interpreted. The following fragments of pottery most likely contained meat from monogastric animals: - two spouts (PII, P8); - cover (PI); - five deniers (P4, P5, P6 and P7); - one belly (Pro). The remaining three samples probably prepared ruminant meat.

In order to verify the above-described results, the methods proposed by S.N.Dudd, R.P.Evershed and A.M. Gibson and B.Hjulström. Dairy products, as well as ruminant meat itself, should have values above 0.015 or $0.02 \mu \mathrm{g} / \mathrm{mL}$. However, the values obtained for the meat of monogastric animals do not exceed: 0.015 or $0.077 \mu \mathrm{g} / \mathrm{mL}$ (Dudda et al. 1999: 1473-1482; cf.: Hjulström et al. 2008: 62-78). With the proposed scale, all the obtained results indicate the presence of ruminant mammal meat in eleven samples. In addition, for samples that were previously considered monogastric meat, there are doubts about the results of the samples PII, P4, P5, PI, PIO, P8, P6, P7. 
Tab. 2. Proportions of fatty acids (Eerkens 2005).

\begin{tabular}{|c|c|c|c|c|c|c|c|}
\hline $\begin{array}{l}\stackrel{\circ}{+0} \\
\stackrel{0}{\alpha} \\
\end{array}$ & $\begin{array}{l}\stackrel{ \pm}{0} \\
\dot{0} \\
\dot{0}\end{array}$ & 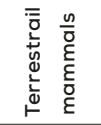 & $\frac{5}{\frac{5}{4}}$ & 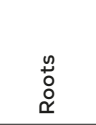 & 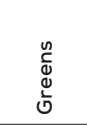 & 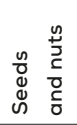 & 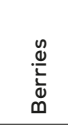 \\
\hline \multirow{2}{*}{$(\mathrm{C} 15: 0+\mathrm{C} 17: 0) / \mathrm{C} 18: 0)$} & fresh & $<0,2$ & $0,2-0,5$ & $>0,2$ & $0,1-1,0$ & $<0,6$ & $<0,2$ \\
\hline & degraded & $<0,2$ & $0,2-0,5$ & $>0,2$ & $0,1-1,0$ & $<0,6$ & $<0,2$ \\
\hline \multirow{2}{*}{ C16:1/C18:10 } & fresh & $0,02-0,2$ & $0,2-0,5$ & $0,05-0,7$ & $>0,7$ & $<0,3$ & $<0,08$ \\
\hline & degraded & $0,08-0,8$ & $0,8-2,0$ & $0,2-2,8$ & $>2,8$ & $<1,2$ & $<0,32$ \\
\hline \multirow{2}{*}{ C16:0/C18:0 } & fresh & $<3,5$ & $4-6$ & $3-12$ & $5-12$ & $0-9$ & $2-6$ \\
\hline & degraded & $<7$ & $8-12$ & $6-24$ & $10-24$ & $0-18$ & $4-12$ \\
\hline \multirow{2}{*}{ C12:0/C14:0 } & fresh & $<0,15$ & $<0,15$ & $>0,15$ & $>0,15$ & $>0,15$ & $>0,15$ \\
\hline & degraded & $<0,15$ & $<0,15$ & $>0,15$ & $>0,15$ & $>0,15$ & $>0,15$ \\
\hline
\end{tabular}

After carrying out the above analyzes, the results are neither accurate nor satisfactory. Therefore, the third method of analysis of the origin of fatty acids was used, which was proposed by M.E. Malainey (1997). The formula (C15: O + C17:) / (I2: O + Ci4: O + Ci6: O + Ci8: o) allows to calculate the ratio of pentadecanoic, margaric, lauric, myristic, palmitic and stearic acids. If the obtained result exceeds $0.04 \mu \mathrm{g} / \mathrm{mL}$, ruminant meat remains in the sample. On this basis, it was found that in ten samples, remains of this type of meat were found. Additionally, in the case of samples no. P3, P5, PI, PIO, P7, the following milk acids were also extracted: caproic acid (c6:0), caprylic acid (c8:0) and capric acid (CıO: O). In the case of four samples, it is a kind of confirmation of the obtained results (P5, PI, PIO, P7). Moreover, in the case of samples that gave divergent results using the previous methods, it was possible to confirm the presence of ruminant meat in them: PII, P4 and P6. On the other hand, sample No. 8 became problematic due to the obtained borderline result (the previous two methods also gave divergent results) - perhaps it was in this dish that meat dishes of various species of mammals were prepared.

Another element of the diet of the inhabitants of the Teutonic castle, the presence of which was checked on the basis of analyzes of the ratio of stearic (Cı8: o) to palmitic (Cı6: O) acids, are fish (sea and freshwater). With this type of food, the obtained result should be less than $0.48 \mu \mathrm{g} / \mathrm{mL}$. In addition, arachidic acid (C2O: O) should also be among the detected fatty acids. Another necessary condition for sample definition is the advantage of palmitic (Cı6: o) over stearic (Cı8: O) (Isaksson 2000). Out of the twelve tested pottery fragments, in one case one may have doubts about the food content of this vessel. In sample no. P7, the advantage of 
Ci6: O acid over Cı8: $\mathrm{O}$ is visible. Moreover, the ratio of both acids is very close to the limit given by S. Isaksson - it is $0.49 \mu \mathrm{g} / \mathrm{mL}$. For the remaining samples, no similar results were detected.

The last stage of the analysis of the obtained results was the application of the acid ratio formulas proposed by J.W. Eerkens (Tab. 2). Ratios of pentadecanoic (C15:0), margaric (Cı7: O), stearic (Cı8: O), palmitic (Cı6: o), oleic (Cı8: I n-9), palmitic (CI6: I n-7) acids and lauric (CI2: 0 ) and myristic (CI4: O), are an attempt to distinguish fat residues of mammals, fish, vegetables, root plants, seeds and nuts and berries (Eerkens 2005: 83-102). Although these proportions were originally invented for North American dishes, they also began to be used to test the content of Polish dishes (Kałużna-Czaplińska et al. 2016: 173-209). Based on the above-mentioned fatty acids, the following summary of the results for each sample was prepared (Tab. I).

In the case of three samples ( $\left.\mathrm{P}_{3}, \mathrm{P} 9, \mathrm{P} 8\right)$ it was possible to calculate the proportion between all of the above-mentioned fatty acids. On this basis, the presence of mammalian meat residues was found in each of the tested samples (confirmed by at least three equations used). In addition, the presence of vegetables was detected in each of the tested samples. Additionally, the remains of root plants, nuts and seeds prepared in dishes were separated.

The next group are fragments of vessels (PII, P2, P4, P5, PI, PIO, P6, P7), in which the detected fatty acids made it possible to use the following acid ratios: pentadecanoic (CI5: O), margaric (CI7:O) and stearic (CI8:0), in the second case palmitic

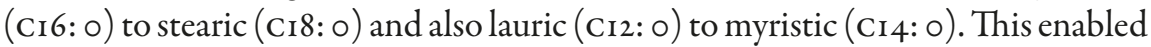
the identification of residues of mammalian meat, nuts and seeds, and vegetables in the nine samples. Trace amounts of blueberries were also detected.

Moreover, in the case of six samples (PII, P2, P3, P6, P9, P7), the possible presence of fatty acid residues from fish was found. In the case of vessel no. 15, it can be concluded that it confirms the presence of this food in the past and corresponds to the result obtained with the above-described method of S. Isaksson.

\section{Summary of the results}

After examining the fatty acids extracted from the fragment of the lid (sample no. I), it is possible to determine what was most likely prepared in the vessel on which it was placed. Most likely it was the meat of ruminants (this was also confirmed by the presence of fatty acids from dairy products). In addition, vegetable, nut and seed residues as well as berry residues were also detected.

Based on the analysis of the content of fatty acids obtained from six fragments of vessel bottoms, it was found that they had contact with such foods as ruminant mammal meat (in the case of samples 3 and 5, this was also confirmed by acids from dairy products - C8: $\mathrm{O}$ and CıO: ०). 
The remains of vegetables, root crops, nuts and seeds were also found. Additionally, five vessels contained four types of insect and plant waxes (P3, P4, P5, P6, P8). Interestingly, beeswax residues were found in all vessel fragments. This may suggest contact with the above-mentioned dishes with the honey that was probably cooked in them. It is therefore necessary to consider the presence of waxes of plant origin. Wax related to lemon balm (C30: o) was detected in seven vessels. Some lemon balm pots may be considered or possibly used as an accompaniment to dishes. Other fatty acids - vegetable waxes could come from plants added as spices. In the case of the presence of waxes, the possibility of waxing the inside of the vessels, which could serve to seal them, can be considered (cf. Salque et al. 2013).

On the other hand, in the fragment of vessel No. 7 fatty acids from fish were isolated, which was confirmed by the two methods presented above. It is the most diverse content of all the tested vessels.

In the case of three belly fragments, two of the meat of ruminants were intensified (in the case of sample No. IO, also confirmed with acids from dairy products), as well as vegetables and root plants.

However, after examining fragment no. 8, it can be concluded that the meat of ruminants and monograsters was most likely prepared in this vessel - due to the discrepancies in the obtained results. In addition to meat, there are also other products: vegetables, nuts, seeds and root crops. In the case of two fragments, it was possible to determine that sample II contained ruminant meat, vegetables, nuts and seeds.

\section{Summary}

Gas chromatography coupled with mass spectrometry made it possible to obtain more than twenty fatty acids from twelve samples taken from fragments of ceramic vessels, from excavations carried out at the castle in Przezmark. It should be emphasized that the obtained qualitative and quantitative results of fatty acids were obtained, which were extracted from fragments of ceramic vessels found in the latrine. Based on the analysis of historic material, i.e. fragments of ceramics, their chronology at the end of the Middle Ages and the beginning of the modern era was determined. Most likely, they were related to the end of the settlement of the castle by the Teutonic Order, but in the latrine itself they were buried in, which could have happened later. Nevertheless, the discovered ceramics were used to conduct analyzes of organic residues in the walls of the vessels, as well as preliminary considerations on the types of dishes that could be prepared in them. The interpretation of the dishes was based on the available results and the formulas used by other researchers.

The conducted analyzes were aimed at determining the type of food prepared in utility vessels. It should be emphasized that the examined food residues came from various elements of the vessels - bellies, bottoms, spouts and covers. It should 
be noted here that, in the case of the lid, there could also be direct contact with the heat-treated food.

Fatty acids of both vegetable and animal origin were extracted from all samples. References regarding the presence of meat and plants were made on the basis of previous research, which now only allows such a distinction between foods cooked in dishes. An important observation was made by scientists who suggested that the volume of the waxes may indicate an attempt to seal the inside of the vessels. Such actions could also take place in the case of the tested pottery fragments.

The methods used above make it possible to analyze the foods that were once prepared in selected vessels, despite their secondary retention in the latrine filling. Moreover, only in a few cases have there been discrepancies in the interpretation of certain types of food. After performing the above analysis, it can be noticed that in all tested samples there were residues of mixed food. It should be emphasized that a small number of fragments of the examined vessels is only a contribution to further research on the diet of the inhabitants of the castle in Przezmark.

\section{Bibliography}

Čiperová M., Pavelka J., Šmejda L. (2015), Detekce stop mléka v porézní keramice z neolitu jihozápadnich Čech a otázka tráveni laktózy u evropských populací $v$ minulosti, Středověká keramika v Čechách a na Moravě - otázky, metody, výsledky “Acta Fakulty filozofické Západočeské univerzity v Plzni”, 7.2, p. 193-2II.

Dudda S.N., Evershed R.P., Gibson A.M.(1999), Evidence for Varying Patterns of Exploitation of Animal Products in Different Prehistoric Pottery Traditions Based on Lipids Preserved in Surface and Absorbed Residues, "Journal of Archaeological Science", 26, p. I473-I482, https://doi.org/10.1006/jasc.1998.0434

Eerkens J.W. (2005), GC-MS Analysis and Fatty Acid Ratios of Archaeological Potsherds from the Western Great Basin of North America, "Archaeometry", 47, p. 83-102, https://doi.org/I0.1111/j.1475-4754.2005.00189.x

Gregg M.W., Slater G.F. (2010), A New Method for Extraction, Isolation and Transesterification of Free Fatty Acids from Archaeological Pottery, "Archaeometry", 52, p. 833-854, https://doi.org/10.1111/j.1475-4754.2010.00518.x

Haftka M. (2010), Zamki krzyżackie. Dzierzgoń - Przezmark - Stum, Wydawnictwo Marpress, Gdańsk.

Hjulström B., Isaksson S., Karlsson C. (2008), Prominent Migration Period Building: Lipid and Elemental Analyses from an Excavation at Alby, Botkyrka Södermanland, Sweden, "Acta Archaeologica", 79, p. 62-78, https://doi.org/ı.IIII/j. I600-0390.2008.00109.x

Isaksson S. (2000), Food and Rank in Early Medieval Time, Stockholm (Theses and Papers in Scientific Archaeology, 3). 
Kałużna-Czaplińska J., Młodecka H. (2008), Badania organicznych pozostatości w ceramice archeologicznej technika GC/MS, [in:] W. Weker (ed.), Nauka i zabytki. Nauki ściste w stużbie archeologii, ochronie zabytków oraz historii, Państwowe Muzeum Archeologiczne, Warszawa, p. I05-ıı.

Kałużna-Czaplińska J., Gątarek P., Rosia A., Kobylińska U., Kobyliński Z. (2016), Zawartość kwasów ttuszczowych w ceramice pochodzacej z pradziejowych iśredniowiecznych grodzisk z zachodniej części ziem pruskich, [in:] Z. Kobyliński, Grodziska Warmii i Mazur, t. II, Nowe badania i interpretacje, Instytut Archeologii Uniwersytetu Kardynała Stefana Wyszyńskiego; Fundacja Res Publica Multiethnica, Warszawa (Archaeologica Hereditas), p. 173-209.

Malainey M.E. (1997), The Reconstruction and Testing of Subsistence and Settlement Strategies for the Plains, Park-land, and Southern Boreal Forest Department of Anthropology, University of Manitoba (unpublished PhD dissertation).

Orliński W., Zdeb K. (2017), Badania archeometryczne wybranych naczyń $z$ cmentarzyska kultury przeworskiej w Legionowie CSP, [in:] W. Nowakowski, W. Orliński, M. Woińska (ed.), Relacje kultury przeworskiej i lateńskiej na Mazowszu. Wnioski z badań cmentarzyska przeworskiego w Legionowie CSP, Instytut Archeologii Uniwersytetu Warszawskiego; Muzeum Historyczne, Warszawa-Legionowo, p. $135-144$.

Pavelka J., Orna J. (2011), Výsledky analýzy potravinových zbytkư na pozdnè stredověké keramice z Plzně, ,Acta Fakulty filozofické Západočeské univerzity v Plzni”, 3, p. $85-98$.

Regert M. (2011), Analytical Strategies for Discriminating Archeological Fatty Substances from Animal Origin, "Mass Sectrometry Reviews", 30, p. 177-220, https://doi.org/10.1002/mas.2027I

Rosiak A., Kufel-Diakowska B., Kałużna-Czaplińska J., Analiza pozostałości organicznych zachowanych w ceramice archeologicznej ze Skoroszowic, Strzelina i Chociwla (poster).

Salque M., Bogucki P.I., Pyzel J., Sobkowiak-Tabaka I., Grygiel R., Szmyt M. (2013), Earliest Evidence for Cheese Making in the Sixth Millennium BC in Northern Europe, "Nature", 493, p. 522-525, https://doi.org/10.1038/natureı1698

Van der Meulen J. (2003), Goudse pijpenmakers en hun marken, Pijpenlogische Kring Nederland, Leiden.

Wunsch C. (1935), Zur Baugeschichte des Schlosses Preußisch Mark vom Ausgang der Ordenszeit bis zum Ende des I8. Jahrhunderts, "Bericht des Konservators der Kunstdenkmäler der Provinz Ostpreußen über seine Tätigkeit im Jahre 1934 an die Provinzialkommission zur Erforschung und zum Schutze der Denkmäler in der Provinz Ostpreußen", 33.

Żurek M. (2018), Zamek pokrzyżacki w Przezmarku. Wstępne wyniki badań, "Archaeologia Historica Polona", 26, p. 283-299, https://doi.org/ı.12775/ AHP.20I8.0I 4

Żurowicz E., Florczak J., Kałużna-Czaplińska J., Lis P., Jóźwik P., Szubiakiewicz E. (2014), Oznaczenia kwasów ttuszczowych w ceramice pochodzacej z wczesnośredniowiecznego zespotu osadniczego w Żmijowiskach, "Analityka", 4, p. 50-53. 


\section{Streszczenie}

Wykopaliska archeologiczne Instytutu Archeologii U Ksw trwały od lipca do sierpnia $2017 \mathrm{r}$. W pierwszym sezonie wykonano cztery wykopy archeologiczne $-\operatorname{trzy}(\mathrm{A}-\mathrm{C})$ na zamku wysokim i jeden (D) na terenie zamku średniego. Wykop A założono na zewnętrznej stronie południowo-wschodniego narożnika zamku. Prace miały na celu weryfikację obecności muru zewnętrznego wybudowanego od strony jeziora, który widoczny jest na planach zamku. Podczas badań wykopaliskowych odsłonięto pozostałości zbiornika - latryny.

$\mathrm{Z}$ tych miejsc wydobywano fragmenty ceramiki użytkowej, które przekazano do laboratorium, aby następnie wyekstrahować kwasy tłuszczowe ze ścianek naczyń ceramicznych. Na podstawie uzyskanych proporcji kwasów tłuszczowych podjęto próbę interpretacji potraw przygotowywanych w naczyniach. Do badań wybrano następujące fragmenty naczyń: wieczko (PI), sześć den (P2, P3, P4, P5, P6, P7), dwa brzuszki (P9, PIO) oraz dwa wyloty (P8 i PII). Po ogólnej analizie stwierdzono, że we wszystkich próbkach wykryto kwasy tłuszczowe pochodzenia roślinnego i zwierzęcego.

Słowa kluczowe: ceramika, chromatografia gazowa sprzężona ze spektrometrią mas, analiza chemiczna, Przezmark

\section{Katarzyna Zdeb}

Cardinal Stefan Wyszyński University in Warsaw

Institute of Archaeology

e-mail: k.h.zdeb@gmail.com

Magdalena Żurek

Cardinal Stefan Wyszyński University in Warsaw

Institute of Archaeology

e-mail: magda.zurek@poczta.onet.pl

(c) by the author, licensee University of Lodz - Lodz University Press, Łódź, Poland. This article is an open access article distributed under the terms and conditions of the Creative Commons Attribution license CC-BY-NC-ND 4.0 (https://creativecommons.org/licenses/by-nc-nd/4.0/) 